\title{
Artesanato com Lixo Eletrônico
}

\author{
Joseane S. de Moraes ${ }^{1}$, Max R. Marinho², Fernando Y. Obana², Lucas K. Sperotto ${ }^{2}$ \\ ${ }^{1}$ Bolsista de Iniciação Tecnológica (FAPEMAT/UNEMAT) - Universidade do Estado \\ de Mato Grosso (UNEMAT) - Alto Araguaia - MT - Brasil \\ ${ }^{2}$ Departmento de Computação - Universidade do Estado de Mato Grosso (UNEMAT) - \\ Alto Araguaia - MT - Brasil \\ joseane.silva.moraes@unemat.br; max.marinhodunemat.br; \\ obana@unemat.br; sperotto@unemat.br
}

\begin{abstract}
Electronic waste is part of the technological evolution we live in and can bring major problems to the environment when improperly disposed of. This work aims to bring another strategy for the recycling and reuse of functional or non-functional discarded electronic equipment.
\end{abstract}

Resumo. O lixo eletrônico faz parte da evolução tecnológica que vivemos e pode trazer grandes problemas para o meio ambiente quando descartado de forma indevida. Este trabalho vem com o objetivo de trazer mais uma estratégia para a reciclagem e reutilização de equipamentos eletroeletrônicos descartados funcionais ou não funcionais.

\section{Introdução}

O lixo eletrônico já é um grande problema mundial devido a seu descarte incorreto, ocasionando grande risco ao meio ambiente. O lixo eletrônico representa 5\% de todo o lixo produzido no mundo, com uma média de 50 milhões de toneladas de resíduo, onde o Brasil possui $1 \%$ deste total com aproximadamente $2,5 \mathrm{~kg}$ por habitante (CEMPRE, 2014). O descarte correto deste tipo de equipamento é de suma importância para o meio ambiente e saúde humana.

O termo lixo eletrônico, conhecido também como e-lixo, se refere ao descarte de aparelhos eletrônicos como computadores, celulares, televisões, rádios antigos (SILVA, J. R. N., 2010). Podemos destacar como uma das causas o avanço tecnológico e o tempo reduzido de vida destes aparelhos. Silva (2010) informa que a preocupação ambiental em relação ao $e$-lixo ser descartado inadequadamente é devido à liberação de substâncias tóxicas que podem vir a causar sérios danos à natureza e ao homem.

Grande parte da população não tem conhecimento sobre o descarte correto de equipamentos eletroeletrônicos, depositando-os em lixos comuns, que em seguida são depositados em aterros sanitários, que em contato com o solo, contaminam-no podendo levar aos lençóis freáticos, e caso forem incinerados, as toxinas são levadas para o ar (OBANA, 2019). A reciclagem destes materiais necessita de um processo adequado para a remoção completa destes metais pesados como chumbo, cobre e outro para poderem ser reutilizados. São pouco locais no Brasil que trabalham com a reciclagem e reutilização desses $e$-lixos e a população muitas vezes nem sabe de sua existência. De acordo com a Política Nacional de Resíduos Sólidos (PNRS - Lei ${ }^{\circ}$ 12.305/2010) uma empresa é responsável por um produto durante todo seu ciclo de vida até seu descarte, onde então a 
reutilização e reciclagem destes dispositivos torna-se uma alternativa para a redução de custos, podendo dar outro fim aos dispositivos descartados.

O projeto de Reutilização e Reciclagem de Equipamentos Eletroeletrônicos (PRREE) que ocorre desde 01/07/2015 na UNEMAT no campus de Alto Araguaia tem como objetivo receber materiais eletroeletrônicos que seriam descartados de forma incorreta, para que se faça uma avaliação do estado destes materiais a fim de que sejam reutilizados, reciclados, ou direcioná-los para descartes adequados quando estiverem inutilizáveis.

Esta proposta vem apresentar mais uma estratégia de reciclagem de componentes eletroeletrônicos, como artesanato de lixo eletrônico, baseada no conceito de Inovação Frugal que visa soluções específicas para certos segmentos que se encontram com fortes restrições de recursos e desenvolvem capacidades para criar soluções de produtos valiosos com redução de custos (KOERICH, 2019). Esta nova estratégia é mais um dos fins que podem ser dados aos componentes eletrônicos descartados, servindo como peças de decoração de resíduo eletrônico, evitando-se o descarte indevido destes equipamentos, diminuindo a contaminação deste resíduo eletrônico na natureza e no mundo. O capítulo 2 deste trabalho trata de como se realizará o trabalho de obtenção e organização de todo o lixo eletrônico bem como propostas de artesanato de lixo eletrônico; já o capítulo 3 aborda as considerações finais, seguido das referências.

\section{Desenvolvimento e Estratégia de Ação}

Esta proposta vai ocorrer no Laboratório de Eletrônica e Sistemas Embarcados (LESE), juntamente com o Centro de Reciclagem e Inovação em Automação e Robótica (CRIAR) que possuem todos os equipamentos devidos para o desenvolvimento da proposta, e o cunho de realizar o descarte correto de dispositivos eletrônicos, bem como reutilizá-los para outros fins. O CRIAR/LESE/PRREE possuem um conjunto de docentes e discentes que já trabalham com reciclagem e reutilização de equipamentos eletroeletrônicos.

Inicialmente buscam-se parcerias público/privadas para o recolhimento de doações da comunidade interna e externa da universidade equipamentos eletrônicos ultrapassados. Com os equipamentos em mãos, inicia-se a etapa de triagem destes equipamentos eletroeletrônicos por meio do processo de desmonte e desmanche de máquinas e outros dispositivos como ilustrado na Figura 1(a) (OBANA, 2021). Após a verificação do funcionamento ou não dos componentes eletrônicos é realizada uma classificação em busca de componentes eletrônicos adequados para a construção de uma peça de decoração com resíduos eletrônicos, ou seja, é uma escolha seletiva com a peça de decoração já idealizada.

A construção de peças decorativas com resíduo eletrônico depende totalmente da imaginação dos membros envolvidos no projeto, indo desde simples caixas para lápis feitas com teclados, passando por relógios feitos com CD em placas de circuitos, até lustres. As peças, futuramente, serão apresentadas em eventos e feiras de ciências, com possibilidade de venda.

Algumas peças decorativas podem envolver anéis com teclas de teclado, porta retratos de telas de celular ou de placas de circuito impresso, porta canetas placas de circuito impresso, relógios com placas de circuito impresso e disco rígido, capas de livros com placas de circuito impresso, entre outros. Algumas peças de artesanato já confeccionadas pelo CRIAR/LESE/RREE estão a seguir conforme indicado na Figura 1(b)-(e). 


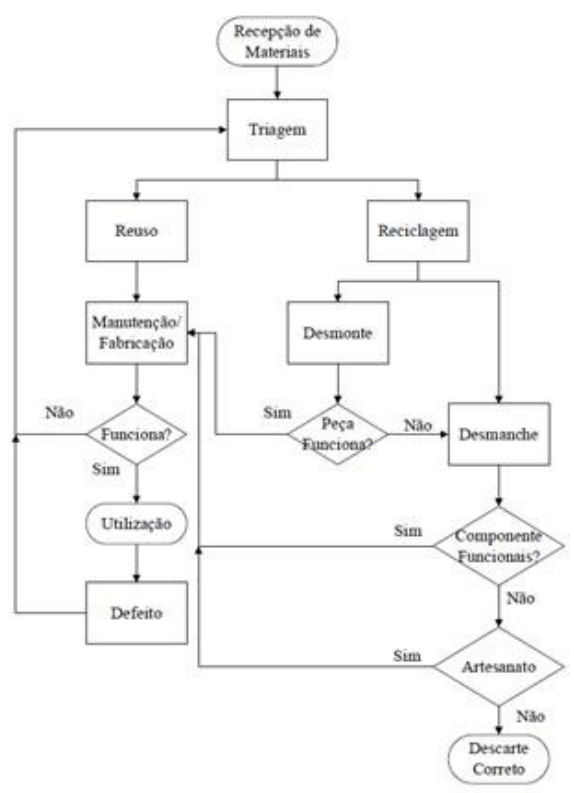

(a)

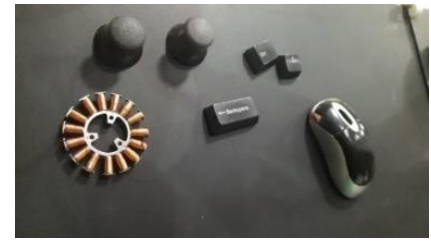

(b)

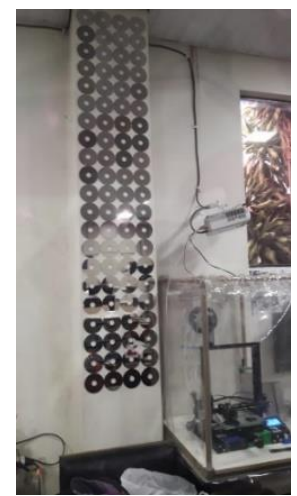

(d)

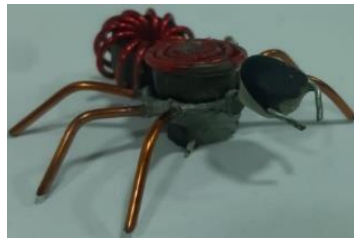

(c)

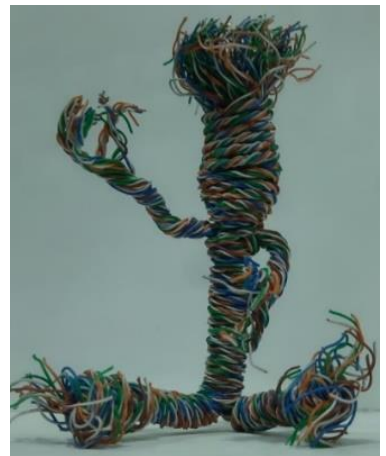

(e)

Figura 1. Fluxograma de descarte e desmanche e peças de Artesanato com Lixo Eletrônico já produzidas - (a) Fluxograma de descarte e desmanche de lixo eletrônico; (b) Painel metálico com itens imantados; (c) Aranha; (d) Decoração de interior com discos de HD; (e) Groot de fios.

\section{Considerações Finais}

Esta proposta busca alcançar novas ideias para a reutilização de dispositivos eletrônicos, conseguindo atingir melhores reaproveitamentos de peças obsoletas com e sem funcionamento. Espera-se, também, que se possa conscientizar melhor a população sobre novas estratégias diferenciadas que podem ser executadas, mesmo dentro de casa, na reutilização de seu lixo eletrônico.

\section{Referências}

CEMPRE: Compromisso Empresarial para Reciclagem. (2014). Disponível em: http://www.cempre.org.br. Acesso em 29/Set/2021.

KOERICH, G. V., CANCELLIER, E. L. P. de L. (2019). "Innovación Frugal: orígenes, evolución y perspectivas futuras”, Cad. EBAPE.BR, v. 17, no. 4, p. 1079-1093, RJ.

OBANA, F. Y., SPEROTTO, L. K., MARINHO, M. R., SANTOS, R. T. dos., (2019). Reutilização e Reciclagem de Equipamentos de Informática em uma cidade de pequeno porte. Revista Compartilhar, v. 3, p. 63-69.

OBANA, F. Y., MARINHO, M. R., SPEROTTO, L. K., ROCHA, T. O., SARUWATARI, F. S., Reciclar é transformar: eletrônica e robótica com resíduos eletrônicos. In: Ciência, tecnologia e inovação: a nova produção do conhecimento 2 Ponta Grossa - PR: Atena, 2021. p. 238-247.

SILVA, J. R. N. da. (2010). Lixo eletrônico: um estudo de responsabilidade Ambiental no contexto do Instituto de Educação Ciência e Tecnologia do Amazonas - IFAM Campus Manaus Centro. Anais do I Congresso Brasileiro de Gestão Ambiental, Bauru-SP. 